Article

\title{
Differences in Tourist Behaviors across the Seasons: The Case of Northern Indiana
}

\author{
Yeongbae Choe ${ }^{1}$ (1) , Hany Kim ${ }^{2}$ (D) and Hyo-Jae Joun ${ }^{3, *}$ \\ 1 Department of Integrated Resort and Tourism Management, University of Macau, Macao SAR, China \\ 2 Department of Tourism and Convention, Pusan National University, Busan 46241, Korea \\ 3 Korea Culture \& Tourism Institute, Seoul 07511, Korea \\ * Correspondence: hjjoun@kcti.re.kr
}

Received: 8 July 2019; Accepted: 9 August 2019; Published: 12 August 2019

check for updates

\begin{abstract}
Seasonality is an essential factor influencing tourism demand and traveler behavior at the destination. As such, seasonality (i.e., the influx of tourists) needs to be managed by destination marketing organizations. Most tourism studies have focused mainly on the forecasting methods/metrics and the effect of seasonality at the aggregate level rather than understanding seasonal differences in the nature of the traveler and travel experience. The purpose of this study is to understand seasonality at both the aggregate market level and individual traveler level. As such, this study first utilizes the concept of the gravity model to understand seasonality in the number of inquiries through an official website. This study, then, uses seemingly unrelated regressions to estimate simultaneously the effect of various trip-related factors on overall trip expenditures and the length of the trip. The results show that the impact of seasonality on aggregated demand is surprisingly consistent across the seasons; however, individual-level analyses indicate that traveler behavior and travelers' responses to advertising differ significantly across seasons. Thus, destination marketers need to understand the nature of seasonality of their specific markets more accurately to provide appropriate tourism products/services to their current and potential travelers.
\end{abstract}

Keywords: Seasonality; tourism demand; expenditure; seemingly unrelated regression; destination marketing; tourism advertisement

\section{Introduction}

Seasonal variation in tourism demand is a critical issue when managing a destination. Defined in terms of the temporal and spatial imbalances in the numbers of visitors, and their behaviors between seasons, the resultant flux of tourists directly influence revenue for tourism businesses within the destination [1-3]. Thus, understanding the effect of seasonality on market structure is indeed essential for destination management organizations (DMOs). By doing so, they can develop effective and suitable specific management strategies based on an economically sustainable method. From DMOs' perspective, destination marketers must prepare and design an appropriate destination management plan to manage tourist demand visiting a destination in both low and high-peak seasons [3,4]. With its practical importance, many researchers have focused on several different issues related to tourism demand and its fluctuation, mainly focusing on causes, impacts, and possible solutions of seasonality [4-10]. These studies document the importance of understanding tourism seasonality and its close connections to all aspects of tourist behaviors at the destination. Furthermore, Parrilla, Font, and Nedal [11], Jang [1], and Segota and Mihalic [10] showed that many DMOs often invest substantially to mitigate seasonality effects through variable pricing, development, or redesigning tourism and hospitality products, and other strategies. 
Seasonality in the destination of tourism can be an imbalance in the distribution of tourist flows throughout the year [7,12]. Therefore, developed and mature tourism destinations often focused primarily on the adjustment of imbalance of tourist flows and the reduction of seasonality by developing various development plans and consolidation strategies $[10,13]$. Indeed, earlier studies showed that tourism destinations often required effective counter-seasonal responses to manage the negative impact of seasonality $[1,6,7]$. For example, DMOs and their marketing specialists have prepared and applied various strategies and policies such as diversification of the product mix, pricing incentives, new market segments, and holiday regulations [10]. Besides, DMOs sometimes hold a temporary special event that attracts more tourists during the shoulder seasons to cope with seasonality issues [14]. In recent years, seasonality has become a more critical problem as it potentially connects with over-tourism issues. Therefore, DMOs and tourism businesses attempt to achieve a balance and redistribute the incoming tourist flows. By doing so, DMOs eventually alleviate the negative impact of tourism seasonality and then solve some social issues related to the tourism industry (e.g., crowding during the peak season and over-tourism).

Tourism seasonality is a very complex social phenomenon that requires diverse solutions for DMOs and marketers to manage both positive and negative issues [15]. In turn, it requires much effort by DMOs to focus on both at the destination level and the individual level. However, it is interesting to note that only a few studies have examined seasonality and its impact on tourist behaviors at the individual level. For example, studies by Bonn, Furr, and Uysal [16], Connell, Page, and Meyer [15], and Yoon and Shafer [17] have explicitly focused on individual travelers and the differences in traveler characteristics and their behaviors between seasons; unfortunately, these studies are mostly descriptive in nature and provide limited insight into travel behavior and the response of travelers to destination advertising. Similarly, not many studies have been conducted to understand the performance of DMOs' marketing and management efforts that respond to seasonality [18]. In this vein, understanding the effect of destination advertising as a solution for seasonality issues would be a vital issue as DMOs often use destination advertising for promoting their destination to overcome seasonal effects to bring more visitors, extend the length of stay, increase tourist expenditures at the destination, and ultimately increase the positive economic tourism impacts [19-22]. It is also able to help redistribute tourist flows across seasons, thereby alleviating the negative impact of seasonality and then eventually enhancing the sustainability of a particular tourism destination.

As such, this research focused on tourism seasonality and its effect on tourist behavior (e.g., length of stay and spending) within the destination. In particular, this study analyzed the impact of seasonality on tourists' behaviors (e.g., information searching, advertising response, length of stays, and expenditure) at both aggregated (e.g., destination) and disaggregated (e.g., individual travelers) levels. Heterogeneity of tourists' behaviors and their responses to destination advertising across different seasons will be expected from our results, which will help DMOs and marketers to design a better destination marketing and management strategy. Therefore, the results will have implications for policymakers and tourism marketers who want to manage their destination in an economically successful way as well as sustainably. This study is structured as follows. Section 2 reviews previous literature including seasonality in tourism, the relationships between seasonality and tourists' behaviors and between seasonality and DMOs activities; Section 3 describes the research design and explains the process of the data preparation; Section 4 presents the results of empirical analyses; and finally Section 5 concludes the current study.

\section{Literature Review}

\subsection{Seasonality in Tourism}

The term seasonality has been applied to situations where there is a temporal and a spatial imbalance in the number of travelers, expenditure, and admissions to attractions [7]. Irregularity (or regularity) is one of the essential characteristics to explain tourism seasonality wherein tourism 
demand and supply fluctuate simultaneously (most likely every year) with more or less the same timing and magnitude in a systematic way $[6,23]$. The most central aspect of seasonality and its effect on tourism demand is the concentration of tourist flows in a short period of the year, and the constant recurrence of the fluctuation of tourist flows throughout the year $[9,24]$. As such, seasonality potentially creates inefficiencies in resource utilization as it produces an excessive burden on the resources of the destination within a relatively short period of a given year. With this practical importance, many earlier studies have focused on the reasons and consequences of seasonality in tourism and travel industry $[1,6,7,25]$. Besides, some studies have been conducted on its measurement and methods to detect the possible seasonality issues in tourism from the perspective of tourism economics or forecasting $[13,14,26-29]$. Besides, many earlier studies used the destination as a unit of analysis for the study, rather than individual tourist [15-17].

Seasonal tourism demand and its variations are the consequences of several interrelated natural and institutional factors $[7,9,12]$. First, natural seasonality includes the effect of changes in natural resources and the environment throughout the year [30-32]. In these studies, climate change, and weather conditions (i.e., temperature, rainfall, the sunshine) are recognized as major and critical forces affecting tourist flows and tourism revenues within a particular destination. Second, institutional seasonality reflects the differences in religious, social, cultural, and ethnic factors that are caused by human actions and policies [7], which are closely related to the social norms and practices of societies [33]. Public holidays and other special events at the specific times of the year such as Christmas and vacations of schools and workplaces are the most common forms of 'seasonality effects' in this category; for example, cultural holidays in some countries generate high volumes of tourism demand and supply, e.g., Thanksgiving Day in the United States, the Golden Week in Japan and the October labor holiday in China. Certain holidays such as Easter or Thanksgiving Day also create variability from year to year because their dates vary and, therefore, may cause changes in its effect on tourism supply and demand [12]. Lastly, other factors have been proposed to create seasonality in travel such as social fashion (e.g., hunting and fishing), sporting event (e.g., Olympic, professional sports), and individual traveler inertia or tradition [7].

\subsection{Seasonality and Travel Behavior}

Seasonality has a vital role in determining tourism demand and travelers' on-site behaviors during the trip. A thorough review of literature in tourism and hospitality also reveals that the notion of push and pull factors in tourism motivation supports the role of seasonality on tourism demand and behaviors $[25,34]$. In this regard, some factors that cause push motivations (e.g., calendar holidays, inertia and tradition, accessibility, and climate in origins) and pull factors (e.g., the climate in destinations, events, and sport) are potentially generating tourism demand from origins to destinations. Moreover, Butler and Mao [25] and Lee [34] argued that the roles of an origin and a destination within the context of tourism and tourist behaviors should be understood differently while understanding the seasonal variations across the time. Tourists may change their travel-related decisions (i.e., whether he/she travels and which destination they would choose) due to various factors which relate to seasons. Institutional seasonality creates (both facilitating and constraining) tourism demand and traveler movements usually solely at an origin throughout the year, whereas natural seasonality influences at both an origin and a destination, which in turn, alter the relative attractiveness of tourism destination over time. For example, school vacations would increase tourism demand for family tourists, but it does not influence any factors related to destinations. Weather-related factors (e.g., hurricane, typhoon, and rainy season) would make tourists to change their travel demand and their potential destination. Besides, seasonality factors would influence tourist behaviors at the destination simultaneously. For example, if tourists living in a colder area visit a sun and beach destination, he/she would participate in different activities than those of residing in a hot area. Or, family tourists with young children would visit a destination with historical attractions for educating their children through travel experiences during their children's vacation and holidays. 
Variations in tourism demand cannot be solely explained by the direction (i.e., push/pull) but also by several individual factors that cause changes in the impact of seasonality on tourism demand and tourist behaviors [25,34-36]. The purpose of the trip cause changes in the potential choice set of a tourism destination and its attractiveness $[25,36]$. For example, a vacation/pleasure trip might be highly related to institutional and natural seasonality as well as DMOs' mitigating effects, whereas a business trip is generally influenced by the business cycle and the resource of the destination. At the same time, visiting friends and relatives may induce additional variations in tourism demand wherein those trips may utilize a discretionary time fitted to their vacation schedule. One's travel distance from the origin to the destination also has an essential impact on changes in destination attractiveness due to seasonality and ultimately tourist behaviors (i.e., travel distance and travel cost) at the destination $[25,34,36]$. Indeed, distance decay is one of the critical factors affecting tourists' decision-making and actual behaviors across the entire trip experience [37-39]. In general, travelers might have different time budgets and desires for traveling to a destination across the year depending on institutional and natural seasonality. Thus, there might be considerable variations in the choice of potential destination as well as averaged travel distance throughout the year. In a similar vein, travel costs, partly associated with tourism seasonality, is another important influencing factor that influences the volume of visitation [36]. A popular tourist destination may cost a lot during the peak-season even if the destination sometimes lowers their prices to attract more travelers, whereas promotional activities during the shoulder season enable travelers to visit the destination more due to decreased travel costs. All these factors potentially alter the decision context of each individual by changing the condition of origins and destinations based on tourism seasonality and, thus, cause changes in mobility both from origins to destinations and within the destination. As such, this study argues that seasonality in tourism demands hugely impact on the tourist behaviors (e.g., the volume of visitation, behaviors at the destination) and possibly reflects the attractiveness of a particular tourism destination and attraction in a given period.

\subsection{Seasonality and Destination Management Organizations (DMOs)}

Butler and Mao [25] further argued that the mechanism of tourism seasonality is not a simple linear relationship but rather the demand (i.e., push factors), supply (i.e., pull factors), and modifying (i.e., modifying activity by DMOs) processes are continuously interacting with each other. Therefore, the dynamic characteristics of tourism demand can be explained by both the effect of seasonality and the mitigating efforts of the DMOs. As such, destination marketers and tourism companies actively respond to these changes in tourism demand and tourists' behaviors due to seasonality. Similarly, an extensive number of studies have examined the impact and consequences of seasonality for destination management [5-9]. Among them, few studies reported that the effects of seasonality are indeed positive to the tourism destinations from the perspective of sociology and economics because it allows tourism destination to be recovered and decentralized during the shoulder season [30]. However, the majority of this research emphasized the negative consequences of seasonality (e.g., instabilities of resource consumption, overcrowding, difficulties in investment, employment, and revenue fluctuations) [5-9]. Importantly, these studies found that seasonality not only alters tourism demand (e.g., number of visitors) but also affects the composition and the characteristics of incoming travelers and related behaviors [36,40].

As such, seasonality has been considered as one of the most essential issues in destination marketing and management to maintain a destination competitive and attractive enough throughout the year. To do so, DMOs often use two distinctive ways of handling the seasonality issues in tourism: (1) lessening seasonality itself and (2) reducing the harmful effects $[1,2,7,11]$. The example of former strategies is developing new tourism products (e.g., attractions, places, events) to generate a new source of tourism demand $[1,8,15]$. Often, destination marketers and tourism companies intentionally create additional tourism demand by holding a promotional event, regardless of its size, during their shoulder season [15]. The latter strategies may require the additional efforts of DMOs and practitioners 
to manage their internal capacities, such as part-time employees, sharing carrying capacity, investing in expansion projects, and ultimately maximizing their marketing and management efficiency $[1,30,41]$. However, both approaches necessitate large investment and effort among stakeholders within the destination $[23,42,43]$. Consequently, marketers try delivering travel information to their potential customers to promote their destination in order to attract visitors throughout the year. As such, DMOs and marketers utilized tourism advertising as a popular promotional tool in that, it is relatively cheaper than other marketing and promotional strategies and makes travelers change perceptions, attitudes, behavioral intention, and even actual behaviors [44-46]. Thus, destination marketers are more likely to adopt various marketing and promotional activities to shape tourism demand and traveler behaviors responding to tourism seasonality.

\section{Methodology}

\subsection{Study Context}

This study applies two different approaches to investigate the effect of DMOs' efforts (i.e., destination promotional activities) responding to tourism seasonality on tourism demand and travelers' behaviors. In doing so, several DMOs in Northern Indiana were selected as a case study. Northern Indiana is a typical Midwestern tourist destination that provides various natural and cultural attractions. The primary target market of Northern Indiana tourism is Metropolitan Chicago as well as small Midwestern cities/towns. The influx of tourists for this destination focuses mainly on the spring and summer seasons (from May to September; approximately $77 \%$ of visitors based on annual visitor surveys). Northern Indiana has diverse tourism products-both natural and cultural attractions, which make Northern Indiana one of the popular tourist destinations in the mid-western part of the US. Thus, this destination represents a typical example of numerous tourism destinations within the United States, which has a diverse composition of different tourism sectors, stakeholders, and attractions within the destination. Lastly, tourism has recently been one of the main economic forces in the destination.

\subsection{Data Preparation for the Aggregated Analysis}

This study first investigates the effect of tourism seasonality on tourism demand at the destination level (e.g., aggregated market demand) by applying a gravity model $[47,48]$ to capture the structure of incoming tourist flows (i.e., tourism demand) from origins to the destination throughout the year. The data used in this analysis were obtained from the local DMOs located in the Midwestern United States and modified as follows. This study first categorizes those populations into the 210 designated market areas (DMAs) based on their physical address (zip code), which describe the geographic area of broadcasting markets [49]. Then, population and the median income for each DMA region were obtained from the United States Census Bureau (www.census.gov) and the United States Department of Labor (www.bls.gov) for each zip code and then aggregated into a data set based on individual DMA regions within the United States. Thus, the final dataset included a set of variables (i.e., total population, median household income, and the number of information inquirers for 10 separate time points) reflecting the characteristics of individual DMA regions which provide the basis for estimating travel demand. This study considers the number of information inquirers as a proxy for tourism demand (incoming tourist flows). Indeed, many travelers in the US visit various websites for their trip planning [50] and, therefore, many studies in tourism have utilized those online traces (e.g., web traffic, search engines) as valuable predictors of their forthcoming travels [51,52]. Therefore, this study used the number of information inquirers from the official website for further analyses.

\subsection{Data Preparation for the Individual Analysis}

The study then conducts a series of cross-tabulation and analysis of variance to identify the differences in demographic and trip characteristics, advertising responses, and trip outcomes (expenditures, the length of trip, satisfaction) between seasons. Seemingly unrelated regression (SUR) is 
also used to simultaneously estimate the effect of the trip and individual characteristics and advertising response on overall trip expenditures and the length of the trip in that both dependent variables (i.e., expenditure and length of trip) are the outcomes of travelers' behaviors and at the same time, highly related to each other. In this situation, SUR provides more efficient and accurate estimated parameters in that the disturbances of the two equations are correlated [53].

The individual-level data were also drawn from advertising evaluation studies during September 2011 to January 2014 (i.e., three surveys per year) and obtained using an online survey of American travelers who had requested travel-related information about the destination from the DMOs' official website and information centers. After excluding invalid and redundant email addresses, a total of 67,209 email invitations were sent out to complete the online survey over the three-year study period. The survey employed the following three-step process to increase the response rate: First, an initial invitation was sent out on Friday along with the URL of the survey so that the respondent would have the weekend to complete the online survey; Second, four days later (on Tuesday) a reminder was delivered to those who had not completed the survey; and, third, the final request for participation was sent out two days later (on Thursday) to those who had not completed the survey. In total, this study received 6058 responses, which equates to a $9.0 \%$ response rate. Of these responses, this study focuses on those respondents who visited the destination, reported participating in activities within the destination, and indicated they spent some money at the destination. As a result of removing the extreme cases (e.g., most prominently for visitor expenditure) and non-visitors, the final sample size was 2444 (40.3\% of total responses).

The questionnaire first asked respondents to indicate whether or not they traveled to or through the destination after requesting travel information. Respondents were then asked to answer questions related to gender, income, trip purpose, the number of previous destination visits, travel party size, the timing of trip planning, and the number of previous destination visits so as to identify travelers and their trip characteristics $[20,45,54,55]$; all variables were measured using single items and then coded into dummy (0/1) variables. Distance from origins to destination was created based on zip code, and their nationality reported by respondents and then coded into a series of four dichotomous $(0 / 1)$ variables (e.g., lives within the state, lives in the next state, lives far from the state but within the United States, and lives outside of the United States). Trip outcomes were measured in terms of overall trip expenditure, the length of trip, overall satisfaction compared to similar trips, and revisit intention. Additionally, the questionnaire included two different types of questions to measure travelers' advertising response depending on trip-related decision facets. Specifically, respondents were asked: "When did you first decide to travel to/through [Destination] before/after regarding the official tourism bureau materials?" For these responses, "After I saw it" was coded a value of 1 and those responding, "Before I saw it", or "Not sure" were coded values of 0 . For the other trip-related decisions (i.e., attractions, restaurants, events, shopping, and accommodations), however, the respondent was asked whether or not they visited a featured place as the result of tourism destination advertising; a dichotomous (0/1) variable was created whereby those responding "yes" were given a value of 1 and those responding "no" or "not sure" were coded values of 0 .

\section{Results}

\subsection{Aggregated-Level Analysis}

The aggregated data analysis used regression analysis to apply a gravity model based upon 10 seasons separately to estimate the tourism demand (i.e., the number of inquiries) from an origin to a destination. The purpose of this analysis is particularly to identify variation in the regression coefficients (i.e., the factors affecting tourism demand) across the different years. The results showed that the coefficients of independent variables appear to be quite stable across the year (see Figure 1). 


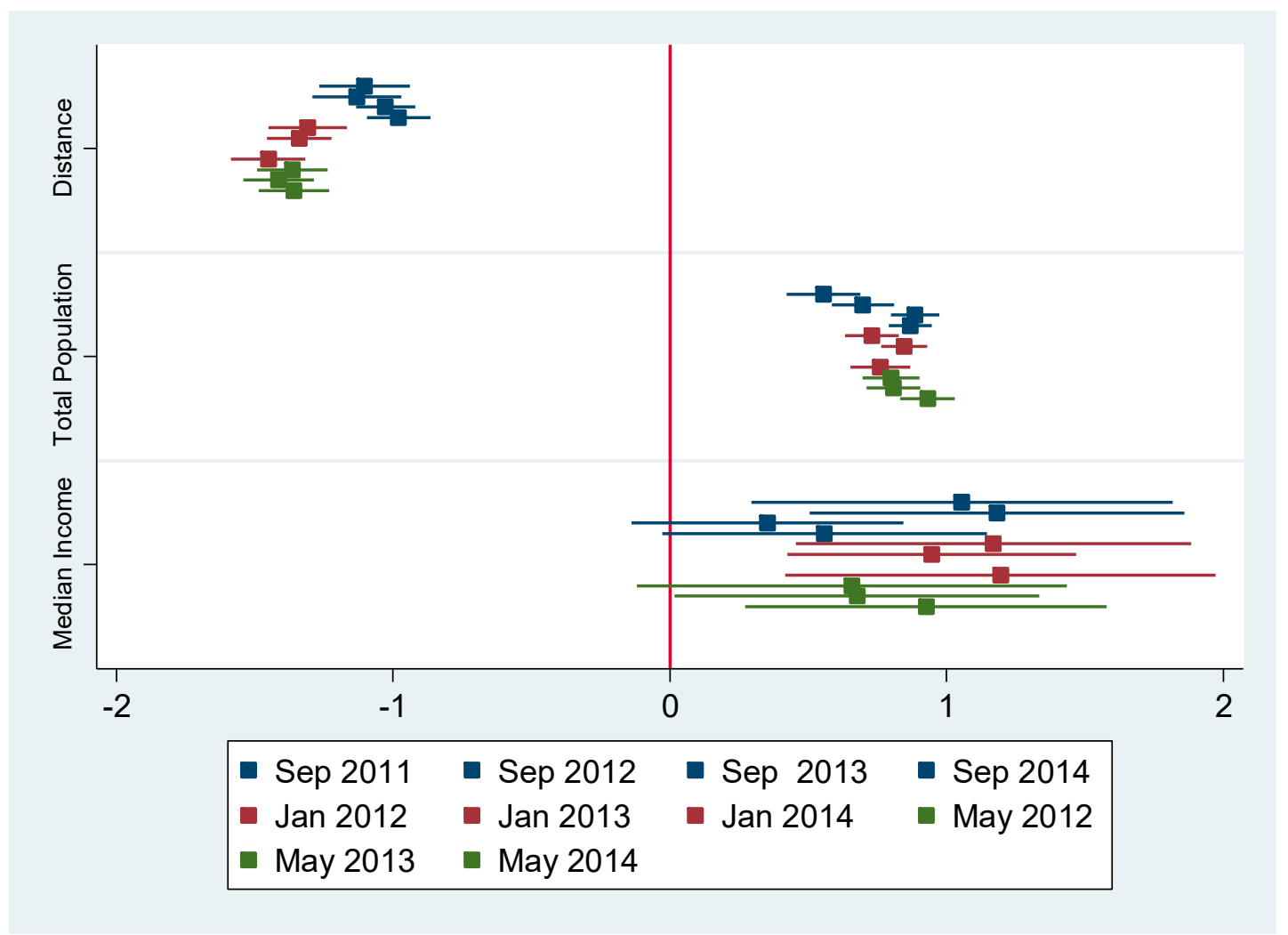

Figure 1. Variation in the regression coefficients across the different years and seasons.

The second step in this process was to investigate the effect of season on tourism demand by combining the data into three separate seasons: Season 1. January-May; Season 2. June-August; and, Season 3. September-December. This categorization of the season follows marketing strategies of the DMOs and historical tourism trends within the study area. Table 1 describes the regression coefficients for three seasons across the year. In general, the gravity model explains the tourism demand well enough (the range of $R^{2}$ is between 85 and 90) based on distance, population, and median income. As expected from previous studies, the physical distance from an origin to a destination has a greater effect on tourism demand, followed by population size and the median income. All explanatory variables (i.e., distance, population, and the median income for the season between January and May between September to December) turned out to be significant predictors explaining the number of inquiries, although the median income for the season between June and August was not statistically significant. Also, a comparison of coefficients using a Z-test [56] reveals that only the effect of physical distance for the season between September and December have a relatively weaker impact on tourism demand, as compared to other seasons.

Table 1. Regression results for three seasons.

\begin{tabular}{cccccccccc}
\hline & \multicolumn{2}{c}{$\begin{array}{c}\text { Season 1 } \\
\text { (Jan.-May) }\end{array}$} & \multicolumn{2}{c}{$\begin{array}{c}\text { Season 2 } \\
\text { (Jun.-Aug.) }\end{array}$} & \multicolumn{2}{c}{$\begin{array}{c}\text { Season 3 } \\
\text { (Sep.-Dec.) }\end{array}$} & \multicolumn{2}{c}{$\begin{array}{c}\text { Difference } \\
\text { (Z-Test) }\end{array}$} \\
\cline { 2 - 12 } & B & SE & B & SE & B & SE & 1 vs. 2 & 1 vs. 3 & 2 vs. 3 \\
\hline Constant & $-8.78^{* *}$ & 3.05 & -5.14 & 2.99 & $-8.96^{* * *}$ & 2.51 & & & \\
Ln (Distance) & $-1.41^{* * *}$ & 0.06 & $-1.45^{* * *}$ & 0.06 & $-1.12^{* * *}$ & 0.05 & $3.75^{* * *}$ & $4.55^{* * *}$ & 0.53 \\
Ln (Population) & $0.88^{* * *}$ & 0.04 & $0.93^{* * *}$ & 0.04 & $0.90^{*}$ & 0.04 & 0.32 & -0.49 & -0.76 \\
Ln (Median Income) & $0.84^{* *}$ & 0.30 & 0.45 & 0.30 & $0.64^{* * *}$ & 0.25 & -0.51 & 0.48 & 0.91 \\
Adjusted $R^{2}$ & 0.85 & \multicolumn{2}{c}{0.89} & & 0.89 & & & & \\
\hline
\end{tabular}

Note: DVs: log-transformed (number of information inquirers), ${ }^{* * *} p<0.001,{ }^{* *} p<0.01,{ }^{*} p<0.05$. 


\subsection{Individual-Level Analysis}

The second stage of the analysis focuses on the effect of seasonality at the individual level. Table 2 summarizes the characteristics of the respondents and their differences between seasons. As can be seen, the majority $(73.5 \%)$ of the respondents are female, and approximately half $(47.6 \%)$ of the sample have an annual household income of at least $\$ 50,000$. About $50 \%$ of the respondents live in the adjacent state, and approximately one-fourth of the sample lives within the state or far from the state but within the United States $(25.6 \%, 23.7 \%$, respectively). Analyses indicate that there are significant differences between seasons in terms of gender $\left(\chi^{2}=6.67, p<0.05\right)$ and distance from an origin to a destination $\left(\chi^{2}=21.00, p<0.001\right)$, but no statistical difference in annual household income $\left(\chi^{2}=19.12, p>0.05\right)$. Based on the pairwise comparisons, those groups visiting between June and August have a slightly higher proportion of female visitors and travelers living far from the state but within the United States. Also, a group visiting between January and May has a higher proportion of tourists living within the state than those of a group visiting between June and August. Based on these results, we can conclude that travelers' characteristics had little impact on travelers' decision to visit the destination across the seasons, but the physical distance to a destination certainly had an important role in determining the decision to visit the destination.

Table 2. Demographic characteristics of survey respondents $(n=2444)$.

\begin{tabular}{|c|c|c|c|c|c|}
\hline & \multicolumn{3}{|c|}{ Season } & \multirow{2}{*}{ Total } & \multirow{2}{*}{$\chi^{2}$ Value } \\
\hline & Jan.-May & Jun.-Aug. & Sep.-Dec. & & \\
\hline & $(21.0 \%)$ & $(49.3 \%)$ & $(29.7 \%)$ & & \\
\hline Gender (\%) & & & & & $6.67 *$ \\
\hline Male & 27.3 & $24.3^{c}$ & $29.7^{c}$ & 26.5 & \\
\hline Female & 72.7 & $75.7^{\mathrm{c}}$ & $70.3^{c}$ & 73.5 & \\
\hline Annual Household Income (\%) & & & & & 19.12 \\
\hline Less than $\$ 20,000$ & 2.7 & 2.4 & 2.2 & 2.4 & \\
\hline$\$ 20,000-\$ 29,999$ & $6.3^{\mathrm{a}}$ & $3.3^{\mathrm{a}}$ & 4.5 & 4.3 & \\
\hline$\$ 30,000-\$ 39,999$ & 7.4 & 5.5 & 7.0 & 6.3 & \\
\hline$\$ 40,000-\$ 49,999$ & 7.6 & 8.8 & 8.8 & 8.6 & \\
\hline$\$ 50,000-\$ 74,999$ & 19.0 & 19.5 & 19.9 & 19.5 & \\
\hline$\$ 75,000-\$ 99,999$ & 15.4 & 14.3 & 13.7 & 14.4 & \\
\hline$\$ 100,000-\$ 149,999$ & 7.8 & 9.2 & 10.8 & 9.4 & \\
\hline$\$ 150,000-\$ 199,999$ & 2.3 & 2.5 & 3.1 & 2.6 & \\
\hline$\$ 200,000$ or more & 1.1 & 2.0 & 1.8 & 1.7 & \\
\hline Do not wish to comment & 30.2 & 32.4 & 28.2 & 30.7 & \\
\hline $\begin{array}{c}\text { Distance from origin to } \\
\text { destination }(\%)\end{array}$ & & & & & $21.00 * *$ \\
\hline Lives within the state & $28.7^{\mathrm{a}}$ & $23.1^{\mathrm{a}, \mathrm{c}}$ & $27.8^{\mathrm{c}}$ & 25.6 & \\
\hline Lives in the next state & 48.5 & 45.1 & 47.0 & 46.4 & \\
\hline Lives far but within the U.S. & $19.4^{\mathrm{a}}$ & $27.2^{\mathrm{a}, \mathrm{c}}$ & $20.8^{c}$ & 23.7 & \\
\hline Lives outside of the U.S. & 3.4 & 4.6 & 4.3 & 4.3 & \\
\hline
\end{tabular}

Note: ${ }^{* *} p<0.001,{ }^{* *} p<0.01,{ }^{*} p<0.05$. Bonferroni's method was used to compare column proportions: ${ }^{a}$ comparison between Jan.-May group and Jun.-Aug. group; ${ }^{b}$ comparison between Jan.-May group and Sep.-Dec. group; ${ }^{c}$ comparison between Jun.-Aug. group and Sep.-Dec. group.

This study also examines the differences in trip characteristics and trip outcomes between three seasonal groups. While only $38.8 \%$ of travelers have no prior visit experience, another one-third $(34.3 \%)$ of respondents had visited a destination more than four times in the past three years. The most common trip purpose is weekend getaway (2-3 days, $32.7 \%)$, followed by day trip $(25.7 \%)$ and vacation (4 days or more, $22.3 \%$ ). The most common time to start planning a trip was between one and four weeks before traveling $(31.0 \%)$, followed by more than two months before $(27.8 \%)$. Slightly 
less than half of the respondents (43.3\%) considered their trip as the same compared to similar trips, whereas approximately $40 \%$ of the sample have gained better tourism experiences.

As can be seen in Table 3, there are significant differences in the number of total visits in the past three years $\left(\chi^{2}=72.75, p<0.001\right)$, trip purpose $\left(\chi^{2}=118.25, p<0.001\right)$, the timing of trip planning $\left(\chi^{2}=49.30, p<0.001\right)$, and revisit intention $\left(\chi^{2}=124.69, p<0.001\right)$ between three seasons. More specifically, during June and August, there are fewer highly experienced visitors (more than four times, $26.7 \%$ ) but more first-time visitors (45.5\%), as compared to other two seasons. More travelers in the group visiting between January and May traveled to a destination with the purpose of a day trip and business meeting/convention than other two seasons. On the other hand, vacation (4 days or more) and attending festival were the more popular trip purposes but visiting family and friends was less common for those who visited a destination between June and August. This finding contrasts with those who visited during June and August started their trip planning earlier than the other two groups (more than two months before the trip, 32.5\%). At the same time, a smaller number of travelers visiting between June and August started their trip planning the day of the trip and between one and six days before traveling. In terms of revisit intention, more travelers who visited between January and May had the intention to revisit a destination $(41.9 \%)$, followed by those who visited between September and December (31.0\%). On the other hand, over one-third (36.5\%) of the sample in the group visiting between June and August did not have any plan to revisit while less than one-fourth of respondents in other two groups had no intention to revisit in the near future. Interestingly, there is no difference in the overall satisfaction compared to similar trips $\left(\chi^{2}=8.76, p>0.05\right)$.

Table 3. Differences in trip characteristics between seasons.

\begin{tabular}{|c|c|c|c|c|c|}
\hline & \multicolumn{3}{|c|}{ Season } & \multirow{2}{*}{ Total } & \multirow{2}{*}{$\chi^{2}$ Value } \\
\hline & Jan.-May & Jun.-Aug. & Sep.-Dec. & & \\
\hline & $(21.0 \%)$ & $(49.3 \%)$ & $(29.7 \%)$ & & \\
\hline Total Visits in the Past 3 Years (\%) & & & & & $72.75 * * *$ \\
\hline Once & $31.9^{\mathrm{a}}$ & $45.0^{\mathrm{a}, \mathrm{c}}$ & $33.3^{c}$ & 38.8 & \\
\hline 2 times & 13.6 & 16.4 & 13.5 & 14.9 & \\
\hline 3 times & 11.6 & 11.9 & 12.4 & 12.0 & \\
\hline 4 times or more & $42.9^{\mathrm{a}}$ & $26.7^{a, c}$ & $40.8^{\mathrm{c}}$ & 34.3 & \\
\hline Trip Purpose (\%) & & & & & $118.25^{* * *}$ \\
\hline Just passing through & 8.3 & 10.6 & 12.2 & 10.6 & \\
\hline Daytrip & $30.3^{a}$ & $21.6^{a, c}$ & $29.2^{c}$ & 25.7 & \\
\hline Weekend getaway: $2-3$ days & 34.2 & 31.6 & 33.2 & 32.7 & \\
\hline Vacation: 4 days or more & $17.3^{\mathrm{a}}$ & $28.1^{a, c}$ & $16.2^{\mathrm{c}}$ & 22.3 & \\
\hline Visit family/friends & $20.6^{\mathrm{a}}$ & $15.1^{\mathrm{a}, \mathrm{c}}$ & $22.1^{\mathrm{c}}$ & 18.3 & \\
\hline Business meeting/convention & $6.1^{\mathrm{a}}$ & $2.8^{\mathrm{a}}$ & 3.8 & 3.8 & \\
\hline Sports tournament & 2.2 & 1.9 & 2.2 & 2.0 & \\
\hline Group tour & 2.4 & 2.8 & 2.1 & 2.5 & \\
\hline Reunion & 2.4 & 2.4 & 2.0 & 2.3 & \\
\hline Attend festival & $4.1^{\mathrm{a}}$ & $8.9^{a, c}$ & $5.3^{\mathrm{c}}$ & 6.8 & \\
\hline Time of Planning (\%) & & & & & $49.30 * * *$ \\
\hline Never planned & 4.5 & 3.0 & 3.6 & 3.5 & \\
\hline Day of trip & $7.0^{\mathrm{a}, \mathrm{b}}$ & $3.0^{\mathrm{a}}$ & $3.1^{b}$ & 3.9 & \\
\hline $1-6$ days before trip & $16.0^{\mathrm{a}}$ & $9.4^{\mathrm{a}, \mathrm{c}}$ & $16.5^{c}$ & 12.7 & \\
\hline 1-4 weeks before trip & 29.4 & 29.5 & 35.1 & 31.0 & \\
\hline 5-8 weeks before trip & 19.0 & 22.6 & 19.7 & 21.0 & \\
\hline More than two months before trip & $24.1^{\mathrm{a}}$ & $32.5^{\mathrm{a}, \mathrm{c}}$ & $22.0^{\mathrm{c}}$ & 27.8 & \\
\hline
\end{tabular}


Table 3. Cont.

\begin{tabular}{|c|c|c|c|c|c|}
\hline & \multicolumn{3}{|c|}{ Season } & \multirow{2}{*}{ Total } & \multirow{2}{*}{$\chi^{2}$ Value } \\
\hline & Jan.-May & Jun.-Aug. & Sep.-Dec. & & \\
\hline & $(21.0 \%)$ & $(49.3 \%)$ & $(29.7 \%)$ & & \\
\hline \multicolumn{2}{|c|}{ Overall Satisfaction compared to similar trips (\%) } & & & & 8.76 \\
\hline Significantly worse & - & 0.7 & 0.3 & 0.4 & \\
\hline Worse & 2.0 & 2.4 & 2.2 & 2.2 & \\
\hline About the same & 44.1 & 43.0 & 43.2 & 43.3 & \\
\hline Better & 28.3 & 26.3 & 27.8 & 27.2 & \\
\hline Significantly better & 15.0 & 15.0 & 16.3 & 15.4 & \\
\hline This was my only trip & 10.5 & 12.7 & 10.3 & 11.5 & \\
\hline Revisit Intention (\%) & & & & & $124.69^{* * *}$ \\
\hline Yes, within the next 3 months & $41.9^{\mathrm{a}, \mathrm{b}}$ & $23.4^{\mathrm{a}, \mathrm{c}}$ & $31.0^{b, c}$ & 29.5 & \\
\hline Yes, 3-6 months from now & $17.5^{\mathrm{a}}$ & $9.3^{\mathrm{a}, \mathrm{c}}$ & $17.8^{\mathrm{c}}$ & 13.5 & \\
\hline $\begin{array}{l}\text { Yes, more than } 6 \text { months from } \\
\text { now }\end{array}$ & $19.2^{a, b}$ & $30.8^{a}$ & $27.0^{b}$ & 27.3 & \\
\hline No & $21.4^{\mathrm{a}}$ & $36.5^{a, c}$ & $24.1^{\mathrm{c}}$ & 29.7 & \\
\hline
\end{tabular}

Note: ${ }^{* * *} p<0.001,{ }^{* *} p<0.01,{ }^{*} p<0.05$. Bonferroni's method was used to compare column proportions: ${ }^{a}$ comparison between Jan.-May group and Jun.-Aug. group; ${ }^{b}$ comparison between Jan.-May group and Sep.-Dec. group; ${ }^{c}$ comparison between Jun.-Aug. group and Sep.-Dec. group.

This study also examines the differences in advertising responses, the length of stay, and overall trip expenditure between seasons (see Table 4). Analyses indicate that there were significant differences in the length of stay $(F$-value $=4.50, p<0.05)$, overall trip expenditure $(F$-value $=3.20, p<0.05)$, and travelers' decision in response to attraction $(F$-value $=4.07, p<0.05)$, restaurant $(F$-value $=4.17, p<0.05)$, and accommodation $(F$-value $=5.42, p<0.01)$ between seasons. However, traveler decisions responding to destination $(F$-value $=1.57, p>0.05)$, event $(F$-value $=0.77, p>0.05)$, and shopping $(F$-value $=2.62, p>0.05)$ did not differ significantly across three seasonal groups in our study; specifically, travelers between June and August had statistically higher means of both the length of stay and overall trip expenditure than travelers between September and December, whereas a season between September and December had the lowest values of the length of stay and overall trip expenditure. In terms of advertising response, travelers visiting during summer appeared to be influenced more by attraction and accommodation-related advertising as compared to those who visited the winter season. However, restaurant related advertising was more influential on traveler decisions between January and May than the rest of the year.

Table 4. Differences in advertising responses, length of stay, and expenditures.

\begin{tabular}{cccccc}
\hline & \multicolumn{3}{c}{ Season } & \multirow{2}{*}{ Total } & \multirow{2}{*}{ F-Value } \\
\cline { 2 - 5 } & Jan.-May & Jun.-Aug. & Sep.-Dec. & & \\
\hline Length of Stay (days) & 2.78 & $3.09^{\mathrm{c}}$ & $2.76^{\mathrm{c}}$ & 2.94 & $4.50^{*}$ \\
Trip Expenditure (\$) & 715.25 & $780.62^{\mathrm{c}}$ & $660.73^{\mathrm{c}}$ & 734.26 & $3.20^{*}$ \\
\hline Advertising responses & & & & & \\
Destination & 0.30 & 0.29 & 0.33 & 0.31 & 1.57 \\
Visit an attraction & 0.53 & $0.56^{\mathrm{c}}$ & $0.49^{\mathrm{c}}$ & 0.53 & $4.07^{*}$ \\
Visit a restaurant & $0.53^{\mathrm{a}, \mathrm{b}}$ & $0.46^{\mathrm{a}}$ & $0.45^{\mathrm{b}}$ & 0.47 & $4.17^{*}$ \\
Attend an event & 0.23 & 0.22 & 0.20 & 0.22 & 0.77 \\
Visit a store/shop & 0.50 & 0.51 & $0.46^{\mathrm{c}}$ & 0.49 & 2.62 \\
Stay in a listed hotel & 0.19 & $0.22^{\mathrm{c}}$ & $0.16^{\mathrm{c}}$ & 0.20 & $5.42^{* *}$ \\
\hline
\end{tabular}

Note: ${ }^{* * *} p<0.001,{ }^{* *} p<0.01,{ }^{*} p<0.05$. Scheffe's posthoc analysis was used: ${ }^{a}$ comparison between Jan.-May group and Jun.-Aug. group; ${ }^{b}$ comparison between Jan.-May group and Sep.-Dec. group; ${ }^{\mathrm{c}}$ comparison between Jun.-Aug. group and Sep.-Dec. group. 
The final analysis in this study examined the influence of DMOs' advertising efforts on individual travelers' behaviors (i.e., expenditure, the length of stay) using seemingly unrelated regression (SUR) to assess the marginal impact of facet-level advertisements response on both overall trip expenditures and the length of stay where the dependent variables were log-transformed and where the moderating variables (i.e., traveler and trip characteristics) were included in the model to exclude the confounding effects. In this study, overall trip expenditure and the length of stay are assumed to be influenced by a set of travelers and trip characteristics and advertising responses simultaneously [57,58]. As such, two separate ordinary least squares (OLS) regression analyses-i.e., for both overall trip expenditure and the length of stay-would provide invalid parameter estimates due to the endogeneity problems and a potential correlation between the error terms in two separate equations. Therefore, SUR potentially solves this problem by estimating the parameters of multiple equations simultaneously [53].

Table 5 shows the SUR estimates and summary statistics for determinants of the overall trip expenditure and the length of stay for three seasons described earlier. All three SUR models show that the Breusch-Pagan test of independence of the residuals rejected the null hypotheses, indicating that the error terms in the two equations (i.e., expenditure, the length of stay) are correlated for all three seasons. The significance of this test indicates that the SUR results are a more efficient and appropriate estimation than two separate OLS estimations. The explanatory level for the individual equations' powers is relatively high with adjusted $R^{2}$ values between 0.50 and 0.60 . Since both dependent variables were log-transformed, the exponentiated form of regression coefficients indicate the changes in the odds ratio of the overall trip expenditure and the length of stay for a one-unit change in the explanatory variable, holding all other variables constant.

The results of the SURS analysis indicate that travelers and trip characteristics and advertising responses had a significant effect on total trip expenditures and the length of the trip across all three seasons but to varying degrees. Only trip purpose (or motivation) had a positive and consistent relationship with both dependent variables for all three seasons. For example, weekend getaway (2-3 days) and vacation (4 days or more) positively associated with both trip spending and the length of stay throughout the year. Of course, day trip purpose shortened the length of the trip. This result is consistent with the earlier tourism demand research, suggesting that the purpose of the trip is one of the most critical determinants of traveler behaviors depending on the seasonality [25,36].

However, the results also reveal several vital differences among the three groups. Firstly, although two types of trip purpose have consistent impacts, the purpose of the trip, in general, had differential impacts on trip spending and the length of stay across the three respective seasons. For example, the coefficients of weekend and vacation on trip spending for the seasons between June and August were relatively lower than other seasons. At the same time, business meeting/conversion purpose significantly related to both spending and the length of stay for those who visited during September and December but not for the group visiting between January and May. Also, group tour and reunion were associated with either trip spending or trip length for a particular season. Secondly, past visit experience only had an impact on those who visited between June and August, but not other seasons. It is important to note that past experiences influenced trip spending but not the length of stay until they visited a destination three times; but once travelers had more than four times, prior visit experience influenced the length of stay as well. Thirdly, the travel party size also correlated with trip spending but not on the length of the trip, suggesting that, on average, larger travel parties spent more money during their trip. However, there was no correlation with trip spending and the length of stay for those who visited between September and December. Fourthly, short trip planning period (i.e., less than one month before traveling) was not correlated with any of the dependent variables; but, longer trip planning had a significant positive impact only on the length of stay for the group visiting between January and May, and on the trip spending for those travelers between June and August. Fifth, the distance from the origin to a destination did influence the length of stay for summer season vacationers (between June and August) and on the trip spending and the length of stay at some extent for those visiting between September and December. Interestingly, physical distance did not correlate with both 
dependent variables for the season between January and May and overall trip spending for the season between June and August.

Table 5. Seemingly unrelated regression (SUR) estimation results.

\begin{tabular}{|c|c|c|c|c|c|c|}
\hline & \multicolumn{2}{|c|}{ Jan.-May } & \multicolumn{2}{|c|}{ Jun.-Aug. } & \multicolumn{2}{|c|}{ Sep.-Dec. } \\
\hline & Spending & $\begin{array}{l}\text { Length of } \\
\text { Stay }\end{array}$ & Spending & $\begin{array}{l}\text { Length of } \\
\text { Stay }\end{array}$ & Spending & $\begin{array}{l}\text { Length of } \\
\text { Stay }\end{array}$ \\
\hline & Beta & Beta & Beta & Beta & Beta & Beta \\
\hline female & 0.15 & -0.02 & 0.02 & 0.01 & $-0.33 *$ & $-0.15^{*}$ \\
\hline$\$ 20,000-\$ 29,999$ & 0.19 & 0.01 & -0.07 & 0.03 & -0.20 & -0.18 \\
\hline$\$ 30,000-\$ 39,999$ & 0.23 & -0.09 & 0.01 & 0.09 & -0.22 & -0.10 \\
\hline$\$ 40,000-\$ 49,999$ & 0.62 & 0.08 & -0.06 & -0.09 & -0.28 & -0.05 \\
\hline$\$ 50,000-\$ 74,999$ & 0.08 & -0.05 & 0.05 & 0.00 & -0.24 & 0.05 \\
\hline$\$ 75,000-\$ 99,999$ & 0.44 & -0.08 & 0.28 & 0.12 & -0.22 & -0.08 \\
\hline$\$ 100,000-\$ 149,999$ & 0.21 & 0.14 & 0.08 & 0.08 & 0.01 & -0.11 \\
\hline$\$ 150,000-\$ 199,999$ & 0.03 & -0.13 & -0.02 & -0.10 & 0.45 & 0.14 \\
\hline$\$ 200,000$ or more & 0.81 & 0.40 & 0.50 & 0.09 & 0.22 & -0.11 \\
\hline Daytrip & 0.13 & $-0.25 *$ & $-0.22 * *$ & $-0.54^{* * *}$ & 0.06 & $-0.28 * *$ \\
\hline Weekend getaway $-2-3$ days & $0.71^{* * *}$ & $0.39^{* * *}$ & $0.48^{* * *}$ & $0.22 * * *$ & $0.81^{* * *}$ & $0.35^{* * *}$ \\
\hline Vacation-4 days or more & $1.22 * * *$ & $0.65^{* * *}$ & $0.86^{* * *}$ & $0.66^{* * *}$ & $1.21^{* * *}$ & $0.79^{* * *}$ \\
\hline Visit family/friends & 0.01 & $0.26 *$ & $-0.27^{*}$ & 0.07 & 0.22 & 0.31 *** \\
\hline Business meeting/convention & 0.62 & -0.06 & -0.03 & 0.31 * & $0.78 *$ & $0.40 *$ \\
\hline Sports tournament & 0.29 & -0.04 & 0.43 & 0.11 & 0.63 & 0.21 \\
\hline Group tour & 0.48 & -0.33 & -0.19 & -0.31 & $-1.25 *$ & -0.23 \\
\hline Reunion & 0.37 & $0.51 *$ & $0.78^{* *}$ & 0.27 & 0.49 & 0.15 \\
\hline Past Experience-2 times & -0.14 & -0.02 & $0.26 *$ & 0.11 & -0.09 & -0.05 \\
\hline Past Experience- -3 times & 0.07 & -0.11 & $0.35 *$ & 0.06 & -0.01 & -0.05 \\
\hline $\begin{array}{c}\text { Past Experience— } 4 \text { times or } \\
\text { more }\end{array}$ & -0.12 & -0.14 & 0.23 * & $0.15^{*}$ & 0.10 & 0.01 \\
\hline Travel Party Size: 2 & -0.05 & -0.01 & 0.09 & -0.05 & 0.18 & 0.06 \\
\hline Travel Party Size: 3-5 & 0.33 & -0.05 & $0.36 *$ & -0.06 & 0.44 & 0.08 \\
\hline Travel Party Size: Over 6 & $1.23^{* * *}$ & 0.25 & $0.79^{* * *}$ & 0.01 & 0.57 & 0.04 \\
\hline Day of trip & 0.30 & 0.52 & -0.34 & -0.30 & 0.08 & 0.18 \\
\hline $1-6$ days before trip & 0.18 & 0.49 & -0.34 & -0.10 & 0.38 & 0.03 \\
\hline 1-4 weeks before trip & 0.36 & 0.47 & 0.25 & -0.03 & 0.64 & 0.26 \\
\hline $5-8$ weeks before trip & 0.74 & $0.64 *$ & 0.36 & 0.07 & $0.87^{*}$ & $0.39 *$ \\
\hline More than 2 months before trip & 0.71 & $0.60 *$ & $0.55 *$ & 0.07 & $0.78 *$ & 0.30 \\
\hline Lives in next state & 0.18 & 0.00 & 0.11 & 0.02 & 0.16 & -0.03 \\
\hline Lives far from state (within US) & 0.42 & 0.14 & 00.21 & $0.14 *$ & 0.29 & $0.28^{* *}$ \\
\hline Lives outside of Unites States & 0.05 & -0.26 & 0.32 & $0.42 * *$ & $0.78 *$ & -0.14 \\
\hline Visit a destination & 0.13 & -0.09 & -0.04 & -0.09 & -0.13 & 0.03 \\
\hline Visit an attraction & 0.12 & 0.18 & 0.14 & $0.10 *$ & -0.01 & 0.13 \\
\hline Visit a restaurant & 0.19 & 0.10 & 0.14 & $0.14^{* *}$ & 0.22 & 0.07 \\
\hline Attend an event & -0.15 & -0.07 & 0.19 & 0.03 & -0.04 & -0.06 \\
\hline Visit a store/shop & 0.07 & 0.07 & $0.37^{* * *}$ & $0.13^{* *}$ & $0.43^{* *}$ & 0.05 \\
\hline Stay in a listed hotel & 0.20 & -0.09 & 0.03 & -0.05 & $0.46^{* *}$ & $0.21 *$ \\
\hline _cons & $4.04^{* * *}$ & 0.03 & $4.52^{* * *}$ & $0.51 * *$ & $4.34^{* * *}$ & 0.25 \\
\hline Adjust $R^{2}$ & 0.52 & 0.51 & 0.50 & 0.60 & 0.50 & 0.59 \\
\hline $\begin{array}{l}\text { Correlation between } \\
\text { the errors of the two equations }\end{array}$ & \multicolumn{2}{|c|}{0.38} & \multicolumn{2}{|c|}{0.32} & \multicolumn{2}{|c|}{0.38} \\
\hline $\begin{array}{l}\text { Breusch-Pagan test } \\
\text { of independence }\end{array}$ & \multicolumn{2}{|c|}{$\begin{array}{l}\chi^{2}=28.07 \\
p<0.001\end{array}$} & \multicolumn{2}{|c|}{$\begin{array}{c}\chi^{2}=44.48 \\
p<0.001\end{array}$} & \multicolumn{2}{|c|}{$\begin{aligned} \chi^{2} & =35.48 \\
p & <0.001\end{aligned}$} \\
\hline
\end{tabular}

Note: ${ }^{* *} p<0.001,{ }^{* *} p<0.01,{ }^{*} p<0.05$. DVs are log-transformed to perform analyses.

Table 5 also shows the regression coefficients for the advertisement response for trip-related decision facets and indicates that the relationships between advertising response and dependent variables (i.e., both total trip expenditures and the length of stay) were substantially different among the three groups. In particular, for the travelers who visited during June and August, advertising 
related to shopping decision influenced to a greater extent overall trip expenditure while advertising related to attraction, restaurant, and shopping decisions influenced the length of stay. On the other hand, the overall trip expenditure for those visiting between September and December were influenced by advertisement response related to shopping and accommodation decisions, whereas only accommodation decision influenced on the decision related to the length of stay. Interestingly, there were no statistically significant impacts for the season between January and May.

\section{Discussion}

Destination marketing organizations often focus much of their efforts on trying to mitigate the effect of seasonality on tourism demand by developing a range of strategies to attract visitors. This study, therefore, aims to understand the differences in tourism demand at the destination level and individual characteristics and tourists' behaviors at the individual level across the seasons. By combining two different levels, the results of this study provide useful information to understand the essential construction of tourism seasonality, which helps to develop a long-term marketing strategy and make a destination economically sustainable.

There are several theoretical and managerial implications. For the theoretical implications, this study empirically confirms the heterogeneity of tourists' behaviors depending on seasons by using analyses at two different levels-i.e., individual and destination. The results from both aggregated and disaggregated analyses are consistent with earlier studies. In particular, a market-level analysis using a gravity model indicates, as previous studies have found [6,23], that tourism demand (and therefore the factors predicting demand) is quite systematic in its response to seasonality in terms of timing and magnitude. Furthermore, physical distance to a destination is the only factor differentiating seasonal demand, which, again, is consistent with the previous research [25,34]. Individual-level analyses also indicate that traveler characteristics and their behaviors differ significantly between seasons. This study includes two separate analyses to understand the individual travelers' behaviors in more detail: (1) identifying the differences in individual and trip characteristics between the seasons; and, (2) comparing the impact of those characteristics on trip spending and the length of stay between the seasons. The findings, consistent with the previous studies $[25,35,36]$, show that distance to a destination, trip purpose, and the number of prior visit experiences in the past three years were essential factors explaining differences in travelers' characteristics between seasons.

From the DMOs' perspective, the results of this study would provide many possible solutions to combat the negative impact of tourism seasonality. In general, this study found that the length of stay and the overall trip expenditures as an outcome of tourism activities at the destination differ significantly between the seasons; besides, advertising responses for trip-related facet decisions vary significantly. These differences might be caused not only by the fact that a destination provides different tourism products/services but also because travelers visiting during a specific season differ significantly in terms of purpose and, therefore, they differ in terms of basic demographic characteristics. These results suggest that DMOs should successfully develop an effective marketing strategy that promotes different aspects of tourist destinations. Second, more importantly, these traveler behaviors (i.e., overall trip spending, the length of stay) respond differently in terms of trip characteristics, and advertising response. In particular, trip purpose, i.e., weekend getaway and vacation, consistently correlates with trip spending and the length of stay across the year, although the magnitude of impacts differs. As such, DMOs may focus on attracting these groups of tourists as they spend more trip-related expenditure and stay longer within the destination, as compared to other groups throughout the year. Third, this study showed differential effects of destination advertising across the seasons. Among advertising responses regarding trip-related decision facets, shopping and accommodation have positive associations with trip spending and the length of stay for those who visited between June and December. Attraction and restaurant-related decisions are related to changes in the length of stay during the summer season (June-August). On the other hand, destination and event-related advertising does not influence traveler behaviors (e.g., expenditure, trip length) throughout the year. However, the results presented 
in this study indicate that the impact of advertising regarding destination and event is consistent across seasons. As such, it is clear from the disaggregated analyses that destination marketers need to be quite sensitive to the seasonal changes in traveler characteristics when designing their marketing programs.

This study has several limitations. First, this study covered only one single destination located in the Midwestern United States. Different tourism destinations will have different demand functions and seasonality. Second, although a gravity model showed relatively higher explanatory powers, this study may neglect some important explanatory variables like destination attractiveness; therefore, further research should consider other variables determining tourism flows and tourism demand. Third, this study considered information inquirers as a proxy for tourism demand at the destination-level analysis. However, it may not fully cover tourism demand accurately. Therefore, a future study should consider other variables to accurately predict future tourism demand. Lastly, this study adjusted for non-response bias potentially existed in the data. However, the collected data might have suffered from selection bias as well. Therefore, future research should put more effort into the data collection procedure. Big data analytics could solve the potential issue related to the selection bias.

Author Contributions: Conceptualization, Y.C., H.K. and H.-J.J.; Data curation, Y.C.; Formal analysis, Y.C.; Methodology, H.-J.J.; Project administration, H.-J.J.; Writing—original draft, Y.C. and H.K.; Writing—review \& editing, H.K. and H.-J.J.

Funding: This research received no external funding.

Conflicts of Interest: The authors declare no conflict of interest.

\section{References}

1. Jang, S.C. Mitigating tourism seasonality-A quantitative approach. Ann. Tour. Res. 2004, 31, 819-836. [CrossRef]

2. De Cantis, S.; Ferrante, M.; Vaccina, F. Seasonal pattern and amplitude-A logical framework to analyse seasonality in tourism: An application to bed occupancy in Sicilian hotels. Tour. Econ. 2011, 17, 655-675. [CrossRef]

3. Turrion-Prats, J.; Duro, J.A. Tourist seasonality in Catalonia: The relevance of demand factors. Tour. Econ. 2017, 23, 846-853. [CrossRef]

4. Turrión-Prats, J.; Duro, J.A. Tourist seasonality and the role of markets. J. Destin. Mark. Manag. 2018, 8, 23-31. [CrossRef]

5. Baum, T.; Hagen, L. Responses to Seasonality: The Experiences of Peripheral Destinations. Int. J. Tour. Res. 1999, 1, 299-312. [CrossRef]

6. Koenig-Lewis, N.; Bischoff, E.E. Seasonality research: The state of the art. Int. J. Tour. Res. 2005, 7, 201-219. [CrossRef]

7. Butler, R.W. Seasonality in Tourism: Issues and Implication. In Seasonality in Tourism; Baum, T., Lundtorp, S., Eds.; Elsevier Ltd.: Oxford, UK, 2001; pp. 5-21. ISBN 0160-7383.

8. Higham, J.; Hinch, T. Tourism, sport and seasons: The challenges and potential of overcoming seasonality in the sport and tourism sectors. Tour. Manag. 2002, 23, 175-185. [CrossRef]

9. Hartmann, R. Tourism, seasonality and social change. Leis. Stud. 1986, 5, 25-33. [CrossRef]

10. Šegota, T.; Mihalič, T. Elicitation of tourist accommodation demand for counter-seasonal responses: Evidence from the Slovenian Coast. J. Destin. Mark. Manag. 2018, 9, 258-266. [CrossRef]

11. Capó Parrilla, J.; Riera Font, A.; Rosselló Nadal, J. Accommodation determinants of seasonal patterns. Ann. Tour. Res. 2007, 34, 422-436. [CrossRef]

12. Baron, R.R.V. Seasonality in Tourism: A Guide to the Analysis of Seasonality and Trends for Policy Making; Economist Intelligence Unit: London, UK, 1975.

13. Duro, J.A. Seasonality of hotel demand in the main Spanish provinces: Measurements and decomposition exercises. Tour. Manag. 2016, 52, 52-63. [CrossRef]

14. Chirieleison, C.; Montrone, A.; Scrucca, L. Measuring the impact of a profit-oriented event on tourism: The Eurochocolate Festival in Perugia, Italy. Tour. Econ. 2013, 19, 1411-1428. [CrossRef]

15. Connell, J.; Page, S.J.; Meyer, D. Visitor attractions and events: Responding to seasonality. Tour. Manag. 2015, 46, 283-298. [CrossRef] 
16. Bonn, M.A.; Furr, H.L.; Uysal, M. Seasonal Variation of Coastal Resort Visitors: Hilton Head Island. J. Travel Res. 1992, 31, 50-56. [CrossRef]

17. Yoon, J.; Shafer, E.L. Models of U.S. Travel Demand Patterns for the Bahamas. J. Travel Res. 1996, 35, 50-56. [CrossRef]

18. Pike, S.; Page, S.J. Destination Marketing Organizations and destination marketing: Anarrative analysis of the literature. Tour. Manag. 2014, 41, 202-227. [CrossRef]

19. Park, S.; Nicolau, J.L.; Fesenmaier, D.R. Assessing advertising in a hierarchical decision model. Ann. Tour. Res. 2013, 40, 260-282. [CrossRef]

20. Stienmetz, J.L.; Maxcy, J.G.; Fesenmaier, D.R. Evaluating Destination Advertising. J. Travel Res. 2015, 54, 22-35. [CrossRef]

21. Pratt, S.; McCabe, S.; Cortes-Jimenez, I.; Blake, A. Measuring the Effectiveness of Destination Marketing Campaigns: Comparative Analysis of Conversion Studies. J. Travel Res. 2010, 49, 179-190. [CrossRef]

22. Perdue, R.R. Segmenting State Travel Information Inquirers by Timing of the Destination Decision and Previous Experience. J. Travel Res. 1985, 23, 6-11. [CrossRef]

23. Cannas, R. An Overview of Tourism Seasonality: Key Concepts and Policies. J. Tour. Cult. Territ. Dev. 2012, 3, 40-58.

24. Allock, J.B. Seasonality. In Tourism Marketing and Management Handbook; Witt, S.F., Moutinho, L., Eds.; Prentice Hall: New York, NY, USA, 1994; pp. 86-92.

25. Butler, R.W.; Mao, B. Seasonality in tourism: Problems and measurement. In Quality Management in Urban Tourism; Murphy, P.E., Ed.; Wiley: New York, NY, USA, 1997.

26. Goh, C.; Law, R. Modeling and forecasting tourism demand for arrivals with stochastic nonstationary seasonality and intervention. Tour. Manag. 2002, 23, 499-510. [CrossRef]

27. Fernández-Morales, A.; Cisneros-Martínez, J.D.; McCabe, S. Seasonal concentration of tourism demand: Decomposition analysis and marketing implications. Tour. Manag. 2016, 56, 172-190. [CrossRef]

28. Lo Magno, G.L.; Ferrante, M.; De Cantis, S. A new index for measuring seasonality: A transportation cost approach. Math. Soc. Sci. 2017, 88, 55-65. [CrossRef]

29. Rosselló, J.; Sansó, A. Yearly, monthly and weekly seasonality of tourism demand: A decomposition analysis. Tour. Manag. 2017, 60, 379-389. [CrossRef]

30. Amelung, B.; Nicholls, S.; Viner, D. Implications of Global Climate Change for Tourism Flows and Seasonality. J. Travel Res. 2007, 45, 285-296. [CrossRef]

31. Becken, S. Measuring the Effect of Weather on Tourism: A Destination- and Activity-Based Analysis. J. Travel Res. 2013, 52, 156-167. [CrossRef]

32. Shih, C.; Nicholls, S.; Holecek, D.F. Impact of Weather on Downhill Ski Lift Ticket Sales. J. Travel Res. 2008, 47, 359-372. [CrossRef]

33. Hinch, T.D.; Hickey, G. Tourism attractions and seasonality: Spatial relationships in Alberta. In Proceedings of the Travel and Tourism Research Association; Canadian Chapter; Mackay, K., Boyd, K.R., Eds.; University of Manitoba: Winnipeg, MB, Canada, 1997; pp. 69-76.

34. Lee, E.S. A theory of migration. Demography 1966, 3, 47-57. [CrossRef]

35. Hinch, T.D.; Jackson, E.L. Leisure Constraints Research: Its Value as a Framework for Understanding Tourism Seasonability. Curr. Issues Tour. 2000, 3, 87-106. [CrossRef]

36. Charles-Edwards, E.; Bell, M. Seasonal Flux in Australia's Population Geography: Linking Space and Time. Popul. Space Place 2015, 21, 103-123. [CrossRef]

37. Choe, Y.; Stienmetz, J.L.; Fesenmaier, D.R. Travel distance and response to destination advertising. Tour. Anal. 2014, 19, 531-539. [CrossRef]

38. Lue, C.-C.; Crompton, J.L.; Stewart, W.P. Evidence of Cumulative Attraction in Multidestination Recreational Trip Decisions. J. Travel Res. 1996, 35, 41-49. [CrossRef]

39. Eldridge, J.D.; Jones, J.P. Warped space: A geography of distance decay. Prof. Geogr. 1991, 43, $500-511$. [CrossRef]

40. Rothman, R.A.; Bates, R.A.; Eckhardt, K.W. The undulating community: A typology of recurrent migrations. Rural Sociol. 1977, 42, 93-100.

41. Kandampully, J. The impact of demand fluctuation on the quality of service: A tourism industry example. Manag. Serv. Qual. 2000, 10, 10-19. [CrossRef]

42. Beritelli, P.; Bieger, T.; Laesser, C. The New Frontiers of Destination Management: Applying Variable Geometry as a Function-Based Approach. J. Travel Res. 2013, 53, 403-417. [CrossRef] 
43. Bornhorst, T.; Ritchie, J.R.B.; Sheehan, L. Determinants of tourism success for DMOs \& destinations: An empirical examination of stakeholders' perspectives. Tour. Manag. 2010, 31, 572-589.

44. Boulding, W.; Lee, E.; Staelin, R. Mastering the mix: Do advertising, promotion, and sales force activities lead to differentiation? J. Mark. Res. 1994, 31, 159-172. [CrossRef]

45. Kim, D.-Y.; Hwang, Y.-H.; Fesenmaier, D.R. Modeling Tourism Advertising Effectiveness. J. Travel Res. 2005, 44, 42-49. [CrossRef]

46. Wöber, K.W.; Fesenmaier, D.R. A Multi-Criteria Approach to Destination Benchmarking. J. Travel Tour. Mark. 2004, 16, 1-18. [CrossRef]

47. Mayo, E.J.; Jarvis, L.P.; Xander, J.A. Beyond the gravity model. J. Acad. Mark. Sci. 1988, 16, 23-29. [CrossRef]

48. Morley, C.; Rosselló, J.; Santana-Gallego, M. Gravity models for tourism demand: Theory and use. Ann. Tour. Res. 2014, 48, 1-10. [CrossRef]

49. Nielsen Media Research Nielson DMA Regions. Available online: https://www.nielsen.com/us/en/intlcampaigns/dma-maps/ (assessed on 10 August 2019).

50. Fesenmaier, D.R.; Xiang, Z.; Pan, B.; Law, R. A framework of search engine use for travel planning. J. Travel Res. 2011, 50, 587-601. [CrossRef]

51. Pan, B.; Yang, Y. Forecasting Destination Weekly Hotel Occupancy with Big Data. J. Travel Res. 2017, 56, 957-970. [CrossRef]

52. Yang, Y.; Pan, B.; Song, H. Predicting Hotel Demand Using Destination Marketing Organization's Web Traffic Data. J. Travel Res. 2014, 53, 433-447. [CrossRef]

53. Zellner, A. An Efficient Method of Estimating Seemingly Unrelated Regressions and Tests for Aggregation Bias. J. Am. Stat. Assoc. 1962, 57, 348-368. [CrossRef]

54. Burke, J.F.; Gitelson, R.E. Conversion Studies: Assumptions, Applications, Accuracy and Abuse. J. Travel Res. 1990, 28, 46-51. [CrossRef]

55. McWilliams, E.G.; Crompton, J.L. An expanded framework for measuring the effectiveness of destination advertising. Tour. Manag. 1997, 18, 127-137. [CrossRef]

56. Paternoster, R.; Brame, R.; Mazerolle, P.; Piquero, A. Using the correct statistical test for the equality of regression coefficients. Criminology 1998, 36, 859-866. [CrossRef]

57. Downward, P.; Lumsdon, L.; Weston, R. Visitor Expenditure: The Case of Cycle Recreation and Tourism. J. Sport Tour. 2009, 14, 25-42. [CrossRef]

58. Thrane, C. On the relationship between length of stay and total trip expenditures: A case study of instrumental variable (IV) regression analysis. Tour. Econ. 2015, 21, 357-367. [CrossRef] 